\title{
Prophylactic diazepam or phenobarbitone in febrile convulsions: a prospective, controlled study
}

\author{
FINN URSIN KNUDSEN AND SVEIN VESTERMARK \\ From the Department of Paediatrics, Glostrup Hospital, University of Copenhagen, Glostrup, Denmark
}

SUMMARY After their first episode of febrile convulsions, 195 previously healthy children, aged 6-30 months, were given either diazepam or phenobarbitone for a year. Each child was assigned at random to one of the two medications: children admitted on even days were given a suppository containing $5 \mathrm{mg}$ diazepam every 8 hours when the rectal temperature was $\geqq 38 \cdot 5^{\circ} \mathrm{C}$. Children admitted on odd days were given treatment with phenobarbitone, $3.5 \pm 1 \mathrm{mg} / \mathrm{kg}$ per day. 156 children completed treatment and outpatient control for a year, 83 in the diazepam and 73 in the phenobarbitone group. The rate of recurrence was independent of the prophylactic and $15-16 \%$ of the children in both groups had new febrile convulsions within a year. The recurrence rate after 6 months was also similar, $11 \%$ in the diazepam group and $9 \%$ in the phenobarbitone group. New convulsions were of similar duration and severity in both groups. In both groups $6 \%$ of all febrile episodes led to new convulsions. Long-term treatment with phenobarbitone thus offered no advantage over intermittent diazepam.

The use of prophylactics for treating febrile convulsions is controversial. Some doctors think that long-term treatment with phenobarbitone is indicated after one episode (Fäerø et al., 1972; Lennox-Buchthal, 1973), others do not (Ouellette, 1974; Heckmatt et al., 1976). Some believe that long-term treatment with phenobarbitone prevents recurrences (Fäerø et al., 1972; Wolf et al., 1977), others consider it of limited or no prophylactic value (Heckmatt et al., 1976). However, nearly all agree that side effects and noncompliance are common (Ouellette, 1974; Thorn, 1975; Heckmatt et al., 1976; Wolf et al., 1977). An alternative prophylaxis, therefore, is needed.

The results are reported from a prospective, randomised investigation of diazepam versus phenobarbitone.

\section{Patients and methods}

The study took place from 1 January 1973 to 1 April 1974. To obtain a homogeneous and well-defined study population, the following criteria were used. (1) Occurrence of first episode of febrile convulsions in connection with an extracranial infection. (2) Age between 6 and 30 months. (3) No clinical signs of chronic, cerebral affection. (4) No previous afebrile convulsions.

A total of 195 children fulfilled these criteria and 156 of them were controlled regularly for one year after their first convulsion. Informed parental consent to the study was obtained for all 195 children, who were randomly assigned to either medication:

1. Intermittent treatment with diazepam for children admitted on even days ( 99 children). The parents were instructed to give one suppository containing $5 \mathrm{mg}$ diazepam (Stesolid ${ }^{\mathrm{R}}$ )* every 8 hours whenever the child had a rectal temperature of $38.5^{\circ} \mathrm{C}$ or above.

2. Continuous treatment with phenobarbitone for children admitted on odd days ( 96 children). Total daily dose was $3 \cdot 5 \pm 1 \mathrm{mg} / \mathrm{kg}$ with one half given in the morning, the other in the evening. Serum phenobarbitone concentration was determined 1-4 times during the observation period and, if possible, when there was a recurrence. The level aimed at was $10-20 \mathrm{mg} / \mathrm{l}$. The determinations were made using gas chromatography (Larsen et al., 1972).

In all other respects examination, treatment, and instruction were similar for both groups. The parents were instructed to uncover the child when febrile. Antipyretics were not given. We recommended that the child should be admitted to hospital

*Dumex, Copenhagen, Denmark. 
if new convulsions occurred. EEG was performed routinely one month after an acute episode. Outpatient control took place every 3-4 months. Parents were questioned about occurrence of fever, new febrile convulsions, compliance with instructions, and side effects. Data were obtained on: the mother's pregnancy, the child's birth, neonatal period, previous illnesses, febrile convulsions or epilepsyand epilepsy or convulsions in parents or siblingssex, age, present disease, and detailed description of first convulsion.

Statistical methods. The P-values were calculated using the $\chi^{2}$ test or Fisher's $\chi^{2}$ test modified for few observations.

\section{Results}

Of the 195 patients, 16 in the diazepam and 8 in the phenobarbitone group were lost to follow-up. In addition, 15 children stopped taking phenobarbitone after 2-6 weeks because of side effects or because their parents had taken a dislike to it. Treatment for one year was thus accomplished in 156 children-83 in the diazepam and 73 in the phenobarbitone group.

The clinical data are given in Table 1 . The two

Table 1 Clinical data

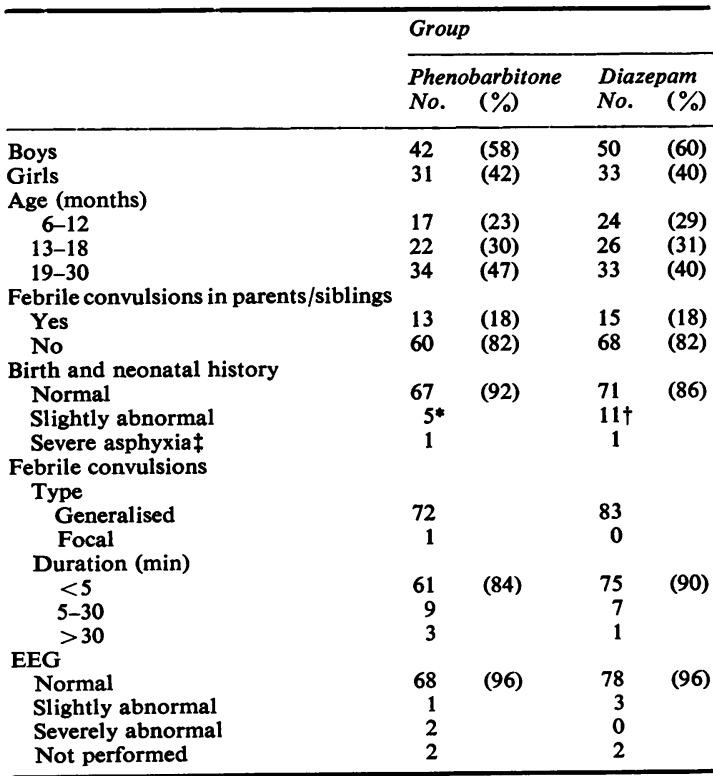

*Includes birthweight 2400-2500 g $(n=3)$, deliveries by caesarean section $(n=1)$, neonatal hypoglycaemia $(n=1)$.

†Includes birthweight $2140-2400 \mathrm{~g}(\mathrm{n}=3)$, deliveries by caesarean section $(n=4)$, extraction by vacuum $(n=1)$, mild respiratory distress syndrome $(n=3)$.

‡Apgar score less than $4 / 5 \mathrm{~min}$. groups were similar with respect to sex, age, duration of convulsions, and EEG findings.

Table 2 shows that the rate of recurrence was similar in both groups, and that new convulsions occurred within one year in $15-16 \%$ of the children. The 6-months' recurrence rate was also similar, $11 \%$ and $9 \%$ respectively, in the diazepam and the phenobarbitone group. The duration of new convulsions was similar (diazepam: range 1-20 min, $\bar{x}=5 \mathrm{~min}$; phenobarbitone: range $\frac{1}{2}-15 \mathrm{~min}, \bar{x}=5$ min). The recurrence rate also remained similar $(15 \%)$ if children with focal and/or protracted $(>30$ min) convulsions, severe asphyxia neonatorum, or abnormal EEG findings were omitted (Table 2). These factors then did not influence the results of treatment.

In Table 3 the two groups are divided according to age at first episode. The treatment had no effect on the recurrence rate in either age group $(P>0.2)$, but if the two groups are combined, recurrences are more common $(0.02<\mathrm{P}<0.05)$ in the younger children.

In both groups $6 \%$ of all febrile episodes led to new convulsions (Table 4). Only 3 children in each

Table 2 Number of recurrences, and recurrence rate within 6 months and within one year in the two groups

\begin{tabular}{|c|c|c|c|c|c|}
\hline & \multirow{3}{*}{$\begin{array}{l}\text { No. of } \\
\text { children }\end{array}$} & \multicolumn{4}{|c|}{ Children with new febrile convulsions } \\
\hline & & \multicolumn{2}{|c|}{ Within 6 months } & \multicolumn{2}{|c|}{ Within one year } \\
\hline & & No. & $(\%)$ & No. & $(\%)$ \\
\hline $\begin{array}{l}\text { Diazepam } \\
\text { Phenobarbitone }\end{array}$ & $\begin{array}{l}83 \\
73\end{array}$ & $\begin{array}{l}9 \\
6\end{array}$ & $\begin{array}{r}(11) \\
(9)\end{array}$ & $\begin{array}{l}13 \\
11\end{array}$ & $\begin{array}{l}(16) \\
(15)\end{array}$ \\
\hline $\begin{array}{l}\text { Diazepam } \\
\text { Phenobarbitone }\end{array}$ & $\begin{array}{l}78^{*} \\
65^{*}\end{array}$ & $\begin{array}{l}8 \\
5\end{array}$ & $\begin{array}{r}(10) \\
(8)\end{array}$ & $\begin{array}{l}12 \\
10\end{array}$ & $\begin{array}{l}(15) \\
(15)\end{array}$ \\
\hline
\end{tabular}

*In the lower part of the table 13 children have been omitted, with protracted convulsions $(>30 \mathrm{~min})(n=4)$, focal convulsions $(n=1)$, severe asphyxia neonatorum (Apgar score $<4 / 5 \mathrm{~min})(\mathrm{n}=2)$, and abnormal EEG $(n=6)$.

Table 3 Age at first convulsions, number of recurrences, and recurrence rate

\begin{tabular}{llll}
\hline & $\begin{array}{l}\text { Age at } \\
\text { first episode }\end{array}$ & $\begin{array}{l}\text { Total no. of } \\
\text { children }\end{array}$ & $\begin{array}{l}\text { Children with } \\
\text { recurrence } \\
\text { (one year) }\end{array}$ \\
\hline Diazepam & $\leqq 13$ months & 24 & $6(25 \%)$ \\
Phenobarbitone & $\leqq 13$ months & 59 & $7(12 \%)$ \\
& $\leqq 13$ months & 17 & $6(35 \%)$ \\
& $>13$ months & 56 & $5(9 \%)$ \\
\hline
\end{tabular}

Table 4 Number of recurrences in relation to total number of febrile episodes

\begin{tabular}{|c|c|c|c|}
\hline & \multicolumn{2}{|c|}{ Total no. within one year } & \multirow{2}{*}{$\begin{array}{l}\text { Recurrence } \\
\text { of febrile } \\
\text { episodes } \\
\%\end{array}$} \\
\hline & $\begin{array}{l}\text { Febrile } \\
\text { episodes* }\end{array}$ & $\begin{array}{l}\text { New } \\
\text { convulsions }\end{array}$ & \\
\hline $\begin{array}{l}\text { Diazepam } \\
\text { Phenobarbitone }\end{array}$ & $\begin{array}{l}228 \\
190\end{array}$ & $\begin{array}{l}14 \dagger \\
12 \dagger\end{array}$ & $\begin{array}{l}6 \\
6\end{array}$ \\
\hline
\end{tabular}

*Defined as $\geqq 38 \cdot 5^{\circ} \mathrm{C}$ during $\geqq 24$ hours.

tOne child in each group had two recurrences during one year. 
group had no febrile episodes during the year of observation. None developed afebrile convulsions.

The Figure illustrates the mean serum phenobarbitone concentration in 65 children with and without recurrence, no determination being made in 8 children. In 7 children the determination was made at the time of recurrence. 129 pheonobarbitone determinations were performed, $76 \%$ with serum levels $>10 \mathrm{mg} / 1$ and $22 \%>15 \mathrm{mg} / \mathrm{l}$. For mean serum phenobarbitone values $<10 \mathrm{mg} / \mathrm{l}$ the recurrence rate was $36 \%$ ( 5 of 14 ), for values between 10 and $15 \mathrm{mg} / 1$ it was $15 \%(6$ of 40$)$ and for a mean serum phenobarbitone of $\geqq 16 \mathrm{mg} / 1$ it was $9 \%$ ( 1 of 11). The inverse correlation between serum phenobarbitone and recurrence rate is not statistically significant $(P>0 \cdot 1)$. The correlation was not significant for serum phenobarbitone values below and above $16 \mathrm{mg} / 1$. For values $<16 \mathrm{mg} / 1$ the recurrence rate was $20 \%$ (11 of 54 ) compared with $9 \%$ for values $\geqq 16 \mathrm{mg} / 1(P>0 \cdot 1)$.

In the diazepam group only one child received diazepam less than 2 hours before a new convulsion. In $11(80 \%)$ of 14 episodes the parents had not managed to give prophylactic treatment in time.

Side effects to phenobarbitone (hyperkinesia, irritability, or listlessness) persisted for more than one month in $42(45 \%)$ of the 96 children. The treatment was stopped after a few weeks in 15 children of whom $3(20 \%)$ had a new episode within one year. No case of intoxication was observed. There were no side effects of diazepam except transient sedation.

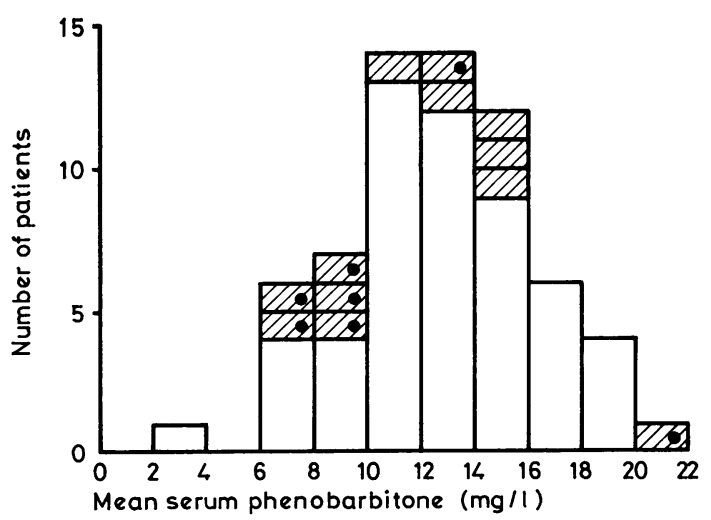

Figure Distribution of mean serum phenobarbitone concentration in 65 children. Recurrences are shown hatched. Black circles indicate that serum phenobarbitone was determined at the time of recurrence. One child had two recurrences.

\section{Discussion}

Recurrence of convulsions was the same whichever prophylactic was used-diazepam or phenobarbitone. The duration and severity of new convulsions were also similar. Long-term treatment with phenobarbitone thus offered no advantage over diazepam.

As we had no control group it is difficult to evaluate the prophylactic effects of the treatments. However, the Gentofte series (Frantzen et al., $1968,1970)$ is comparable. It comprised 172 children who were not given any anticonvulsant treatment. The one-year recurrence rate of $25 \%$ compares unfavourably with that found in our study $\left(\chi^{2}=4.08,0.02<P<0.05\right)$ and others (Wallace, 1974) have found much higher recurrences for untreated febrile convulsions. This suggests that both diazepam and phenobarbitone provide some protection from renewed convulsions.

It might be argued that the phenobarbitone doses used were too low and that the $15-16 \%$ rate in this study population may represent spontaneous recurrences. However, the theory that only a serum phenobarbitone of $\geqq 16 \mathrm{mg} / 1$ effectively prevents new convulsions (Fäerø et al., 1972) has not yet been substantiated in larger and more homogeneous groups of children (Heckmatt et al., 1976). In fact, Wolf et al. (1977) showed that phenobarbitone lowered the recurrence rate to a significant extent despite the fact that $65 \%$ of the phenobarbitone determinations were lower than $15 \mathrm{mg} / \mathrm{l}$.

Our study also showed that the administration of diazepam was not optimal. In $80 \%$ of new episodes the children received the anticonvulsant too late. At the time of the convulsion probably only one child had an anticonvulsant plasma diazepam concentration (i.e. about 200-300 ng/ml) (Agurell et al., 1975; Knudsen, 1977).

Diazepam is a safe and quickly absorbed anticonvulsant, virtually free from undesirable effects (Greenblatt and Shader, 1974) and there is little parental resistance to it. This is in contrast to the well known side effects of phenobarbitone.

In our opinion diazepam may be an alternative prophylaxis in febrile convulsions but further controlled investigations are needed.

\section{References}

Agurell, S., Berlin, A., Ferngren, H., and Hellström, B. (1975). Plasma levels of diazepam after parenteral and rectal administration in children. Epilepsia, 16, 277-283.

Fäerø, O., Kastrup, K. W., Nielsen, E. L., Melchior, J. C. and Thorn, I. (1972). Successful prophylaxis of febrile convulsions with phenobarbital. Epilepsia, 13, 279-285.

Frantzen, E., Lennox-Buchthal, M., and Nygaard, A. (1968). Longitudinal EEG and clinical study of children with febrile convulsions. Electroencephalography and Clinical Neurophysiology, 24, 197-212. 
Frantzen, E., Lennox-Buchthal, M. A., Nygaard, A., and Stene, J. (1970). A genetic study of febrile convulsions. Neurology, 20, 909-917.

Greenblatt, D. J., and Shader, R. I. (1974). Benzodiazepines in Clinical Practice. Raven Press: New York.

Heckmatt, J. Z., Houston, A. B., Clow, D. J., Stephenson, J. B. P., Dodd, K. L., Lealman, G. T., and Logan, R. W. (1976). Failure of phenobarbitone to prevent febrile convulsions. British Medical Journal, 1, 559-561.

Knudsen, F. U. (1977). Plasma-diazepam in infants after rectal administration in solution and by suppository. Acto paediatrica Scandinavica, 66, 563-567.

Larsen, N-E., Naestoft, J., and Hvidberg, E. (1972). Rapid routine determination of some anti-epileptic drugs in serum by gas chromatography. Clinica chimica acta, 40, 171-176.

Lennox-Buchthal, M. A. (1973). Febrile convulsions. A reappraisal. Electroencephalography and Clinical Neurophysiology, 32, Supplement, 1-138.
Ouellette, E. M. (1974). The child who convulses with fever. Pediatric Clinics of North America, 21, 467-481.

Thorn, I. (1975). A controlled study of prophylactic longterm treatment of febrile convulsions with phenobarbital. Acta neurologica Scandinavica, Supplement 60, 67-73.

Wallace, S. J. (1974). Recurrence of febrile convulsions. Archives of Disease in Childhood, 49, 763-765.

Wolf, S. M., Carr, A., Davis, D. C., Davidson, S., Dale, E. P., Forsythe, A., Goldenberg, E. D., Hanson, R., Lulejian, G. A., Nelson, M. A., Treitman, P., and Weinstein, A. (1977). The value of phenobarbital in the child who has had a single febrile seizure: a controlled prospective study. Pediatrics, 59, 378-385.

Correspondence to Dr Finn Ursin Knudsen, Department of Paediatrics, Glostrup Hospital, DK-2600 Glostrup, Denmark. 